\title{
Effect of Replacement of Maize Gluten with Rice Bran (5:0 and 1:4) Feed Supplement on Fish Growth in a Composite Culture
}

\author{
Seyyeda Umme Farwa Naqvi ${ }^{1}$, Ghulam Abbas ${ }^{2, *}$, Nasir Ahmd ${ }^{1}$, Iftikhar Ahmad ${ }^{1}$, \\ Muhammad Khurram Shahzad ${ }^{3}$, Sajid Hussain Qamar ${ }^{2}$ \\ ${ }^{1}$ Department of Zoology and Fisheries, University of Agriculture Faisalabad, Pakistan \\ ${ }^{2}$ Department of Poultry Science, University of Agriculture Faisalabad, Pakistan \\ ${ }^{3}$ Department of Chemistry and Biochemistry, University of Agriculture Faisalabad, Pakistan
}

Copyright $(\mathcal{C} 2015$ by authors, all rights reserved. Authors agree that this article remains permanently open access under the terms of the Creative Commons Attribution License 4.0 International License.

\begin{abstract}
This experiment was conducted to evaluate comparative effect of replacement of maize gluten with rice bran feed supplement on fish growth in composite culture. Two earthen ponds, each measuring 30m x 16m x $1.5 \mathrm{~m}$ (length $\mathrm{x}$ width $\mathrm{x}$ depth) were stocked with 100 Labeo rohita, 50 Cirrihina mrigla and 25 Ctenophayrngon idella. Pond P1 was provided maize gluten and rice bran with a ratio 5:0 whilst pond P2 was provided maize gluten and rice bran with a ratio 1:4. Average body weight gain, fork length and total length were affected significantly by replacing maize gluten with rice bran. Results indicated that it is better to supplement maize gluten (30\% CP): rice bran 1:4 for more yield as compared to maize gluten (30\% CP) alone.
\end{abstract}

Keywords Fork Length, Rice Bran, Maize Gluten, Cirrihina Mrigla, Ctenophayrngon Idella, Labeo Rohita

\section{Introduction}

Rapid growth in human population forecasting several problems including food shortages, malnutrition and protein deficiency challenges especially that of animal origin. Fish meat is an important dietary animal protein source of high biological value and can significantly contribute and help in alleviating food shortages globally. It is an important source of nutrients as it contains all essential amino acids, essential fatty acids particularly omega-3 polyunsaturated fatty acids, vitamins and minerals especially iodine, phosphorus, potassium, iron, copper in desirable concentrations whilst carbohydrates in a very low level $[22,20]$. Basic fertility of the water body and supply of supplementary feeds largely affect the fish growth and natural productivity of fishes may be improved provided with supplementary feeds [5].

Species interactions among fishes also important and suitable selection of fish in composite culture can boost nutrient level [18,21]. Sustainable and successful freshwater fish culture on scientific basis principally depends upon the use of adequate, economically viable and environment friendly artificial feeds. Since the feed costs vary between 40 to $60 \%$ of the total managerial expenditure in fresh water fish culture system, provision of artificial feed increases the fish growth and production in the fertilized ponds and results in higher growth rates and yields. It is noted that fish supplemented with more crude protein in feeds showed significantly better growth as compared to that supplemented with low crude protein feeds [1].

Pakistan is enriched with marine and island fisheries resource of a great potential which can participate significantly in human food supply chain [8]. Composite Fish Culture (production of two or more fish species within a particular aquaculture environment) technology is the most sustainable system of fish production in Asian region [3]. Supplemental feeds are used to fortify the natural available diet with extra protein, carbohydrates or lipids. Supplementary feeds are less expensive agricultural or animal by-products used to increase productivity of ponds. Maize bran and rice bran have been used in ponds as feed supplement in many studies (Kadongola 1991; Fitzmmons et al. 1999; Veverica et al., 2000) but a little research work has been done to evaluate effects of different supplementary feeding on growth performance of fish in composite culture system. Therefore the present study was designed to envisage the effect of replacement of maize gluten with rice bran (5:0 and 1:4) feed supplement on fish growth in a composite culture.

\section{Materials and Methods}

\section{Experimental facilities}


The experiment was carried out in two earthen ponds, each measuring $30 \mathrm{~m} \times 16 \mathrm{~m} \times 1.5 \mathrm{~m}$ (length $\mathrm{x}$ width $\mathrm{x}$ depth) located at Fisheries Research Farm, University of Agriculture, Faisalabad. To disinfect these ponds and to stabilize $\mathrm{pH}$ of water, liming was done with calcium oxide. The inlets of ponds were properly screened with gauze of fine mesh to avoid the entry of any intruder in to or exit of fish from ponds. All the ponds were watered up to a level of $1.5 \mathrm{~m}$ and this water level maintained throughout the experimental period.

\section{Experimental Fish species}

Both ponds were stocked with 100 Labeo rohita, 50 Cirrihina mrigla and 25 Ctenophayrngon idella.

\section{Feeds and feeding}

Fishes in treated ponds were supplied with maize gluten (30\% CP) and rice bran at a rate of 5:0 and 1:4daily from May 31, 2007 to November 02, 2007.

\section{Data Recording}

At the time of stocking the morphometric characteristics of fish e.g. body weight and total length, recorded and then fishes were released in to their respective ponds samples containing $1 / 5$ fishes of each species were randomly captured after 15 days from these ponds by nylon drag net. Their body weight and total length were recorded and these fishes were then released back in to their respective ponds after morphometric analysis. The growth rate of the cultured species was taken as increase in body weight and total length.

\section{Statistical analysis}

The collected data were subjected to analysis of variance (ANOVA) using a Micro Computer IM-PC and means were compared using Duncan's multiple range tests [23]

\section{Results}

Analysis of variance showed significant differences in body weight gain among fish species in each fortnight (fourteen days interval) and supplement treatment (Table 1). In pond 1 Ctenophayrngon idella gained maximum weight of $76.9 \mathrm{~g}$ in $11^{\text {th }}$ fortnight, Labeo rohita gained maximum body weight of $53.2 \mathrm{~g}$ during $5^{\text {th }}$ fortnight whilst Cirrihinus mrigla gained maximum body weight of $39.5 \mathrm{~g}$ during $7^{\text {th }}$ fortnight. In pond 2 Ctenophayrngon idella gained maximum weight of $72.6 \mathrm{~g}$ at $9^{\text {th }}$ fortnig5445443wszht, Labeo rohita gained maximum body weight of $55.9 \mathrm{~g}$ during $5^{\text {th }}$ fortnight whilst Cirrihinus mrigla gained maximum body weight of $37.3 \mathrm{~g}$ during $8^{\text {th }}$ fortnight. As regard the increase in average fork length varied significantly (Table 2) from a minimum increase of $2 \mathrm{~cm}$ at day 19/10/2007 to maximum increase of $2.9 \mathrm{~cm}$ at day 08/09/2007 for Labeo rohita, a minimum of $1.2 \mathrm{~cm}$ at $11 / 07 / 2007$ to a maximum of $2.8 \mathrm{~cm}$ at 14/06/2007 for Cirrihinus mrigla whilst maximum and minimum increase in fork length in Ctenophayrngon idella were $1.7 \mathrm{~cm}$ at 28/06/2007 and $4.4 \mathrm{~cm}$ at day 05/10/2007 respectively in pond1. As well as increase in average fork length in pond 2 is concerned, its minimum and maximum increase for Labeo rohita were $1.6 \mathrm{~cm}$ at day 22/09/07 and $2.9 \mathrm{~cm}$ at date 19/10/2007 respectively. Minimum and maximum increase in average fork length of Cirrihinus mrigla was $1.8 \mathrm{~cm}(05 / 10 / 2007)$ and $2.9 \mathrm{~cm}$ (25/07/2007) respectively whilst these values for Ctenophayrngon idella were recorded as $1.9 \mathrm{~cm} \mathrm{(08/08/2007)} \mathrm{and} \mathrm{‘t4.5} \mathrm{cm}$ (02/11/2007).

Feed supplements showed a significant effect on average total length of fish species in composite culture (Table 3). Increase in average total length of Labeo rohita, Cirrihina mrigla and Ctenophayrngon idella in experimental pond 1 were a minimum of $1.8 \mathrm{~cm} \mathrm{(25/07/2007),} 1.6 \mathrm{~cm}$ (11/07/2007), $1.9 \mathrm{~cm}(11 / 07 / 2007)$ and maximum $3.2 \mathrm{~cm}$ (02/11/2007), $3.6 \mathrm{~cm}(02 / 11 / 2007)$, and $5.4 \mathrm{~cm}(19 / 10 / 2007)$ for these species respectively. Increase in average total length of Labeo rohita, Cirrihina mrigla and Ctenophayrngon idella in experimental pond 2 remained a minimum of $1.8 \mathrm{~cm}$ (25/07/2007), $1.8 \mathrm{~cm}(08 / 09 / 2007)$ and $1.8 \mathrm{~cm}(11 / 07 / 2007)$ and maximum $3.9 \mathrm{~cm}(02 / 11 / 2007)$, $2.8 \mathrm{~cm}(25 / 07 / 2007)$ and $3.6 \mathrm{~cm}(02 / 11 / 2007)$ for three fish species respectively.

Table 1. Fortnight increase in weight gain of carps in pond 1 and 2

\begin{tabular}{|c|c|c|c|c|c|c|c|}
\hline \multicolumn{7}{|c|}{ Wight gain (g) } \\
\hline \multicolumn{2}{|c|}{ P1 } \\
\hline Fortnight & $\begin{array}{c}\text { Labeo } \\
\text { rohita }\end{array}$ & $\begin{array}{c}\text { Cirrhinus } \\
\text { mrigla }\end{array}$ & $\begin{array}{c}\text { Ctenopharygodon } \\
\text { idella }\end{array}$ & $\begin{array}{c}\text { Labeo } \\
\text { rohita }\end{array}$ & $\begin{array}{c}\text { Cirrhinus } \\
\text { mrigla }\end{array}$ & $\begin{array}{c}\text { Ctenopharygodon } \\
\text { idella }\end{array}$ & Means \\
\hline $14-6-2007$ & 34.2 & 20.2 & 55 & 39.2 & 30.5 & 58.5 & $39.6 \mathrm{C}$ \\
\hline $28-6-2007$ & 46.8 & 26.4 & 66.5 & 48.3 & 32.3 & 65.6 & $47.65 \mathrm{AB}$ \\
\hline $11-7-2007$ & 39.9 & 30.8 & 71.4 & 43.7 & 34.2 & 68.3 & $48.05 \mathrm{AB}$ \\
\hline $25-7-2007$ & 53.2 & 24.7 & 75.6 & 55.9 & 32.4 & 69.4 & $51.87 \mathrm{~A}$ \\
\hline $8-8-2007$ & 51.9 & 33.6 & 70.8 & 40.1 & 35.5 & 60.7 & $48.77 \mathrm{AB}$ \\
\hline $22-8-2007$ & 47.3 & 39.5 & 60.4 & 48.9 & 32.5 & 61.3 & $48.32 \mathrm{AB}$ \\
\hline $8-9--2007$ & 40.9 & 36.3 & 63.3 & 51.2 & 37.3 & 69.3 & $49.72 \mathrm{AB}$ \\
\hline $22-9-2007$ & 39.2 & 28.4 & 50.5 & 44.2 & 33.5 & 72.6 & $44.73 \mathrm{BC}$ \\
\hline $5-10-2007$ & 36.9 & 26.8 & 54.4 & 49.8 & 32.4 & 59.9 & $43.37 \mathrm{BC}$ \\
\hline $19-10-007$ & 47.2 & 34.6 & 76.9 & 48.6 & 36.3 & 70.6 & $52.37 \mathrm{~A}$ \\
\hline $2-11-2007$ & 37.9 & 37.4 & 66.7 & 54.2 & 29.3 & 69.5 & $49.17 \mathrm{AB}$ \\
\hline
\end{tabular}


Table 2. Fortnight increase in Fork length gain of carps in pond 1 and 2

\begin{tabular}{|c|c|c|c|c|c|c|c|}
\hline \multicolumn{7}{|c|}{ Fork length gain(g) } \\
\hline \multicolumn{7}{|c|}{ P1 } \\
\hline Fortnight & $\begin{array}{c}\text { Labeo } \\
\text { rohita }\end{array}$ & $\begin{array}{c}\text { Cirrhinus } \\
\text { mrigla }\end{array}$ & $\begin{array}{c}\text { Ctenopharygodon } \\
\text { idella }\end{array}$ & $\begin{array}{c}\text { Labeo } \\
\text { rohita }\end{array}$ & $\begin{array}{c}\text { Cirrhinus } \\
\text { mrigla }\end{array}$ & $\begin{array}{c}\text { Ctenopharygodon } \\
\text { idella }\end{array}$ & Means \\
\hline $14-6-2007$ & 2.4 & 2.8 & 1.9 & 1.8 & 2.6 & 2.1 & $2.3 \mathrm{BC}$ \\
\hline $28-6-2007$ & 2.9 & 2.2 & 1.7 & 1.7 & 2.4 & 2.2 & $2.183 \mathrm{C}$ \\
\hline $11-7-2007$ & 2.4 & 1.2 & 2.0 & 2.1 & 1.9 & 2.2 & $1.967 \mathrm{D}$ \\
\hline $25-7-2007$ & 2.8 & 2.4 & 2.2 & 2.4 & 2.9 & 2.4 & $2.52 \mathrm{ABC}$ \\
\hline $8-8-2007$ & 2.7 & 1.9 & 1.8 & 1.9 & 2.4 & 1.9 & $2.1 \mathrm{CD}$ \\
\hline $22-8-2007$ & 2.2 & 1.8 & 2.9 & 2.2 & 2.2 & 2.3 & $2.267 \mathrm{BC}$ \\
\hline $8-9--2007$ & 2.9 & 2.1 & 3.4 & 1.8 & 1.9 & 2.1 & $2.367 \mathrm{BC}$ \\
\hline $22-9-2007$ & 2.2 & 2.2 & 3.9 & 1.6 & 2.5 & 2.2 & $2.43 \mathrm{BB}$ \\
\hline $5-10-2007$ & 2.7 & 2.3 & 4.4 & 1.9 & 1.8 & 2.8 & $2.65 \mathrm{AB}$ \\
\hline $19-10-007$ & 2.0 & 1.8 & 3.8 & 2.9 & 1.9 & 2.9 & $2.55 \mathrm{ABC}$ \\
\hline $2-11-2007$ & 2.4 & 2.1 & 3.2 & 2.6 & 2.9 & 4.5 & $2.95 \mathrm{~A}$ \\
\hline
\end{tabular}

Table 3. Fortnight increase in Total length gain of carps in pond 1 and 2

\begin{tabular}{|c|c|c|c|c|c|c|c|}
\hline \multicolumn{7}{|c|}{ Total length gain (g) } \\
\hline \multicolumn{7}{|c|}{ P1 } & \multicolumn{7}{c|}{ P2 } \\
\hline Fortnight & $\begin{array}{c}\text { Labeo } \\
\text { rohita }\end{array}$ & $\begin{array}{c}\text { Cirrhinus } \\
\text { mrigla }\end{array}$ & $\begin{array}{c}\text { Ctenopharygodon } \\
\text { idella }\end{array}$ & $\begin{array}{c}\text { Labeo } \\
\text { rohita }\end{array}$ & $\begin{array}{c}\text { Cirrhinus } \\
\text { mrigla }\end{array}$ & $\begin{array}{c}\text { Ctenopharygodon } \\
\text { idella }\end{array}$ & Means \\
\hline $14-6-2007$ & 1.9 & 1.9 & 2.2 & 2.4 & 2.1 & 2.2 & $2.12 \mathrm{C}$ \\
\hline $28-6-2007$ & 2.2 & 2.5 & 2.1 & 2.2 & 1.9 & 2.4 & $2.22 \mathrm{BC}$ \\
\hline $11-7-2007$ & 2.3 & 1.6 & 1.9 & 2.1 & 2.4 & 1.8 & $2.02 \mathrm{C}$ \\
\hline $25-7-2007$ & 1.8 & 2.2 & 2.2 & 1.8 & 2.8 & 2.3 & $2.183 \mathrm{C}$ \\
\hline $8-8-2007$ & 2.6 & 2.1 & 2.4 & 2.4 & 1.9 & 2.2 & $2.267 \mathrm{BC}$ \\
\hline $22-8-2007$ & 2.4 & 3.2 & 2.9 & 1.9 & 2.6 & 1.9 & $2.48 \mathrm{BC}$ \\
\hline $8-9--2007$ & 2.0 & 2.4 & 2.6 & 2.1 & 1.8 & 2.4 & $2.22 \mathrm{BC}$ \\
\hline $22-9-2007$ & 1.8 & 1.9 & 3.4 & 2.0 & 2.4 & 3.2 & $2.45 \mathrm{BC}$ \\
\hline $5-10-2007$ & 3.0 & 2.4 & 3.8 & 3.4 & 1.8 & 2.9 & $2.88 \mathrm{AB}$ \\
\hline $19-10-007$ & 3.2 & 2.0 & 5.4 & 3.2 & 2.2 & 3.2 & $3.2 \mathrm{~A}$ \\
\hline $2-11-2007$ & 3.2 & 3.6 & 4.0 & 3.9 & 2.4 & 3.6 & $3.45 \mathrm{~A}$ \\
\hline
\end{tabular}

\section{Discussion}

All the organisms are influenced by their surroundings. The surroundings consist of several physiochemical and biological components. The most important influencing factor in aquatic ecosystem on growth of organisms is feeding. Supplementary feeding nourishes fish with the additional proteins and good carbohydrates, which results in better weight gain [11]. The growth rate is a good tool to check the acceptability of supplementary feed in fish feeding experiments $[2,10]$. Supplementary feeding may enhance carrying capacity of culture systems by several folds $[12,16,17]$. In the present study, the average maximum fortnightly weight gain was highest of Ctenophayrngon idella (76.9g) in Pond 2 which was provided with maize gluten and rice bran in $1: 4$ ratio, at $11^{\text {th }}$ fortnight e.g. 19-10-2007. Results are in accordance with the findings of Diana et al. [6] and Khan et al. [15] who reported more weight gained response in fish provided rice bran as compared to other feed supplements. The maximum weight gain of Labeo rohita was recorded in the month of July during $4^{\text {th }}$ fortnight $(53.2 \mathrm{~g})$. Maximum weight gain of Cirrhinus mrigala was recorded in the month of August during $6^{\text {th }}$ fortnight (39.5g), whilst maximum weight gain of Ctenopharyngodon idella was recorded in the month of October during $11^{\text {th }}$ fortnight (76.9g). These findings are in accordance with the findings of Hussain et al. [9] who investigated that duration had significant impact on growth performance of fish in terms of weight, fork length and total length increments.

During June to August the pond water temperature ranged between $26^{\circ} \mathrm{C}$ and $33^{\circ} \mathrm{C}$ might be suitable for the growth of Labeo rohita and Cirrhinus mrigala. At these temperatures fish fed extensively on natural and supplementary feeds [4]. Similar results are also reported by Rashid (1985) that fish activities including growth and development greatly depends on temperature. Growth potential of Ctenopharyngodon idella is higher than indigenous species i. e. Labeo rohita and Cirrhinus mrigala. Kanak [14] reported that in polyculture of exotic carps, silver carp performed the highest mean 
length and weight gain (30.7 cm and 513.0g). Indigenous species have approximately similar growth potential. The results of the present investigation also revealed that fortnights exerted significant effect on weight gain, fork length gain and total length gain of fishes. During the comparative study of ponds maximum gain obtained in P2 which was provided with maize gluten and rice bran in 1:4 ratio.

Supplementary feed: maize gluten and rice bran in 1:4 ratio, showed significant effect on average weight, average fork length and average total length of fish species in composite culture. Hossain et al. [6] investigated significant highest production of fish from rice bran + mustard oil cake supplemented feed [7]. Better performance of fish species fed on supplementary feeds with higher crude protein was also reported by Joshi et al. [13] and Sunder et al. [24]. The results of the present study revealed that it is better to supplement maize gluten (30\%) and rice bran 1:4 in order to maximize the production of composite fish culture. These results have significant practical importance in encouraging and maximizing the production of composite fish culture with the use of supplementary feeding to enhance the production potential. These findings can support fish farmers and in terms can improve the economics of the fish farming sector.

\section{REFERENCES}

[1] Abbas, K., I. Ahmed, M.H. Rehman and S. Kanwal. 2004. Effect of rice bran and maize gluten on the growthperformance of major carps in fertilized ponds. Indus J. Plant Sci. 3: 391-395.

[2] Ahmad, I., K. Abbas and M. H. Rehman. 2005. Growth response of major carps in semi-intensive ponds supplemented with rice polishing. Pak. Vet. J. 25 (2): 59-62.

[3] Azad, M.A.K., M.R. Rahman, Z. Rahman, M.A. Kader, M.M. Haque and M.J. Alam, 2004. Polyculture of carp, tilapia and pangas using low cost inputs. Pakistan J. Biol. Sci., 7(11): 1918-1926.

[4] Bettoli, P. W., W. H. Neill and S. W. Kelsch, 1985.Temperature preference and heat resistance of grass carp Ctenopharyngodon idella, bighead carpHypophthalmichthys nobilis and their F1 hybrids. J. Fish Biol., 27: 239-247.

[5] De-Silva, S.S. and M.R. Hasan. 2007. Feeds and fertilizers: the key to long-term sustainability of Asian aquaculture. In: Study and Analysis of Feeds and Fertilizers for Sustainable Aquaculture Development. Ed. M.R. Hasan, T. Hecht, S.S. De-Silva and A.G.J. Tacon), p. 19-48 FAO Fisheries Technical Paper No. 497, Rome.

[6] Diana, J. S., C. K. Lin and K. Jaiyen, 1994.Supplemental feeding of Tilapia in fertilized ponds. J. World Aquacult. Society, 25: 497-506.

[7] Hossain M. I., S. Ahmed, M. S. Reza, M. Y. Hossain, M. nurulislam, J. Ara \& Rafiqul islam. 2013. Effects of organic fertilizer and supplementary feeds on growth performance of silver carp (HYPOPHTHALMICHTHYS MOLITRIX) and bata(CIRRHINUS REBA) fry in nursery ponds. Int. J. of Res. in Applied, Natural and Social Sci. (IJRANSS). 1:117-124

[8] Hussain, M., S.M. Hussain, M. Afzal, A. Javid, S. Abdullah, S.A. Raza and M. Iqbal, 2011. Effect of low level of mineral phosphorus and medium level ofNitrogen on planktonic productivity and increase in fish Production. The Journal of Animal \& Plant Sciences, 21: 642-645

[9] Hussain, S.M., M. Javed, S. Asghar, M. Hussain, S. Abdullah, S.A. Raza and A. Javid. 2010. Studies on growth performance of metals mixture stressed Cirrhina mrigala in earthen ponds. Pak. J. Agri. Sci. 47: 263-270.

[10] Inayat, L. and M. Salim, 2005. Feed conversion ratio of major carp, Cirrhinus mrigala, fingerlings fed on soybean meal, maize gluten and maize. Pakistan Vet. J., 25(1) : 13-17.

[11] Jena, J. K., S. Ayyapan P. K. Aravindakshan, B. Dash, S. K. Sahu, S. K. Singh and H. K. Muduli, 2002. Evaluation of production performance in carp polyculture with different stocking densities and species combinations. J. Appl. Ichthyol., 18: 165-171.

[12] Jhingran, V. G., 1995. Fish and Fisheries of India.Hindustan Publishing, Delhi, India.

[13] Joshi, C.B., K.L. Sehgal and K.C. Malkani. 1989.Experimental trials on feeding of Tor putitora with formulated diets at Bhimtal in Kumaon Himalayas. Indian J. Anim. Sci. 59: 206-209.

[14] Kanak, M. K. 1997. Performance of exotic fishes in polyculture with Indian major carps under three different species combinations. M. S. Thesis, Department of Aquaculture and Management, BAU, Mymensingh. 74 pp.

[15] Khan, M. A., A. K. Jafri and N. K. Chadha, 2004. Growth, reproductive performance, muscle and egg composition in grass carp, Ctenopharyngodon idella (Valenciennes), fed hydrilla or formulated diets with varying protein levels. Aquacul. Res., 35: 1277-1285.

[16] Kabir, A.N., M.A. Hossain and M.S. Rahman. 2009. Use of duckweed as feed for fishes in polyculture. J. Agric. Rural. Dev. 7: 157-160.

[17] Nazish, N. and A. Mateen. 2011. Winter growth of carps under different semi-intensive culture conditions. Pak. Vet. J. 31: 134-136.

[18] Rahman, M. A., M. K. Hossain., M. A. K. Azad., M.Kamruzzzaman., H. A. Rashid., M. M. Rahman and K. M. M. Hasan. 2006. Culture potentialof Thai Sharpunti, Barbodes gonionotus (Bleeker) with major carps in seasonal ponds.Pakistan J. Biol. Sci., 9(10): 1891-1897.

[19] Rashid, R. 1985. The effect of mannure fertilization on growth of catla catla. M. Sc. Thesis, Department of Zoology and Fisheries, University of Agriculture, Faisalabad, Pakistan.

[20] Razvi, M. (2006). Lahore-absolutely fishy: Nutritional value. The Review, Dawn, 12-13pp.

[21] Sahu, P. K., J. K. Jena, P. C. Das, S. Mondal and R. Das. 2007. Production performance of Labeo calbasu(Hamilton) in polyculture with threeIndian major carps Catla catla (Hamilton), Labeo rohita (Hamilton) and Cirrhinus 
mrigala(Hamilton) with provisions of fertilizers, feed and periphytic substrate as varied inputs. Aquaculture, 262: 333-339.

[22] Sandhu, G.S. (2005). A Textbook of Fish and Fisheries. Dominant Publishers and Distributors, New Delhi. 39-40pp.

[23] Steel, R.G.D., J.H. Torrie and D.A. Dickey. 1996. Principles and Procedures of Statistics, 3rd Ed. McGraw Hill International Book Co., New York. p. 336-352 USA.

[24] Sunder, S., H.S. Raina and U. Naulia. 1998. Preliminary feeding trials on juveniles of golden mahseer, Tor putitora (Ham.) at different stocking densities with artificial dry pellet feeds. Ind. J. Ani. Sci. 68: 410-416. 